\title{
Developing EFL Oral Communication Skills and Motivation through Vlogging \\ Prepared by
}

\author{
Dr. Hanan Ahmed Sanad
}

English Language Teacher

Sharkyya Governorate, Minya Elkamh

\begin{abstract}
It is necessary to exploit and include innovative advances into the learning process and use them effectively and creatively to present solutions to daily problems. This research has twofold aims: to assess the effectiveness of using vlogs in developing college students' oral communication skills, and to examine EFL college students' motivation to learn. The design includes one pre-post experimental group. The group sample consists of 166 students of humanities track enrolled in the preparation year ,department of English language at Imam AbdulRahman Bin Faisal University, KSA. They were pretested to determine their oral communication entry-level. They were also taught how to improve their oral communication skills through the sessions of the program. The test was repeated to assess the students' performance progress. Analysis of the results indicated that the use of vlogs had little effect in improving oral communication skills and motivation among EFL PYP learners.
\end{abstract}

Keywords: vlogging; internet; video platforms, oral communication, motivation. 


\section{Developing EFL Oral Communication Skills and Motivation through Vlogging}

ملخص البحث

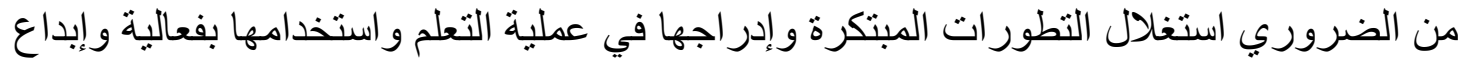

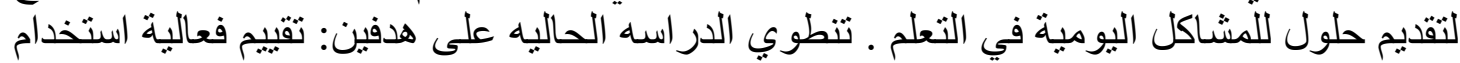

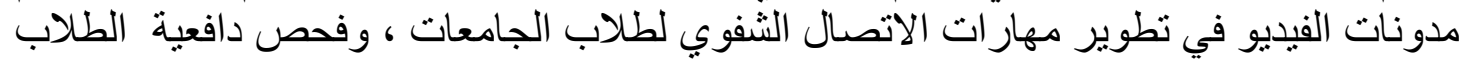

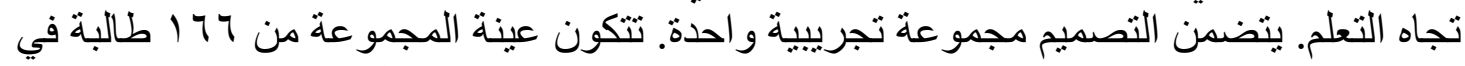
مسار العلوم الإنسانية مسجلين في السنة التحضيرية بقسم اللغة الإنجليزية بجامعة الإمام عبد التبانة

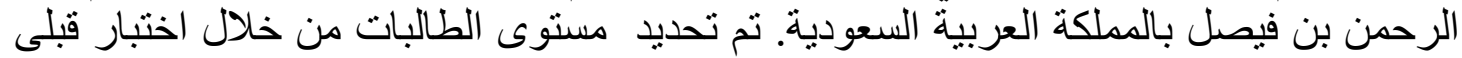

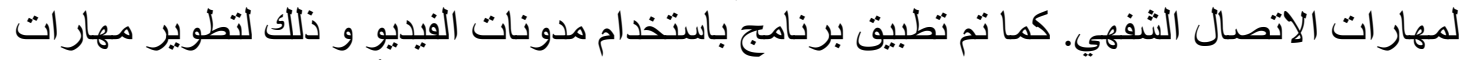

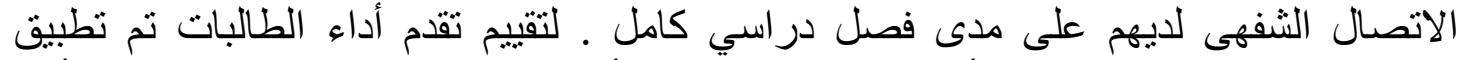

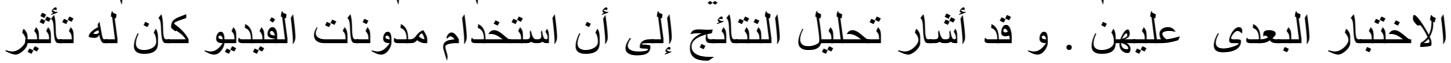
ضئيل في تحسين مهار ات الاتصال الثيار الثفوي و التحفيز بين متعلمي اللغة الإنجليزية كلغة أجنبية . الكلمات ألمفتاحية: انين مدونات الفيديو ـ الانترنت ـ منصات الفيديو ـ الاتصال الثفهى ـ الدافعيه 


\section{Developing EFL Oral Communication Skills and Motivation through Vlogging Prepared by

\author{
Dr. Hanan Ahmed Sanad
} \\ English Language Teacher \\ Sharkyya Governorate, Minya Elkamh}

\section{Introduction}

The focus of the learning process is to keep the learners active, motivated, and engaged all the time. Therefore, it is more fruitful and effective to focus on learner-centered approaches (LCA). Since technology plays a significant role in the learners' daily life, it becomes inevitable and promising to incorporate it into the learning process. The plethora of modern technology revolution has paved the way for new channels of interaction inside and outside EFL classrooms. Using social media is among the latest trends. One of the most effective tools is Blogs. Using blogs whether audio or video attracts learners in many fields as it is an interactive tool that meets the learners' needs and interests. Taking into consideration the revolutionary role of the Internet and its useful applications, video blogs (vlogs) are being used as an effective educational tool in different content areas with different goals.

Vlogs have been widely used and applied in improving EFL skills. They can be implemented to develop both productive and receptive skills as well as teachers' use of teaching methods (Bacescu, 2017). It is one of many opportunities that enrich the quality of teaching and learning especially among adults.

EFL learners interact actively and enthusiastically with this learning environment both internally and externally. Brinton (2001,p461) believes that social media applications play a significant role as a powerful motivator in language teaching because of the reality of the situation in the classroom which improves their use of vocabulary inside and outside the classroom.

\section{Definition of vlogs}

Video blogging (Vlogging) has gained much interest all over the world. Online Cambridge English Dictionary defines a vlog as "a record of news, opinions, etc., about a particular subject that someone puts on the internet) the contents of which are mainly video." "Vlog forms always incorporate audio file (or a video link) with text, images as well as other metadata that promote it. Records can be published in one shot in several bits or split into multiple parts. Matheson (2004) defines blogs as "online websites in which users can continuously update their works/artefacts." Hung (2011: 736-737) adds that blogs/ vlogs provide digital media 
contexts in which people can document their artifacts and observations that govern their development and skills.

\section{Rationale of Vlogging}

According to Anil (2016) and Watkins (2012), a considerable rationale to use vlogs as a healthy learning approach is that it maximizes learners' oral communication time and helps improve vocabulary and grammar as well as wear shyness away. They agree that using vlogs has many advantages and positive effects such as:

1. It increases the students' talking time (STT).

2. It improves mastery of vocabulary and grammar.

3. It promotes fluency and confidence.

4. It decreases shyness.

5. It encourages self-monitored speaking.

6. It considers the teacher's feedback.

The main advantage of utilizing videos in class is access to real English and the development of independent and student-centered learning styles (Watkins and Wilkins, 2011). Also, the inclusion of technology into the classroom - especially amongst low-level students or ESP students — has been shown to promote greater student involvement and develop long-term English language skills (Leung, 2004).

\section{Motivating students}

Based on the constructivist educational activities, Blogs have the potential to develop intellectual development in many ways, such as by motivation (Noel, 2015). Studies ensure the positive impact of blogs on the participants' desire to learn course content, essentially since they give students a concentration on the learning experience (Comas-Quinn, et. al.; 2009). Weblogs, as an online journal, are important to the learners' everyday life. Weblogs allow them to make choices about compelling content and interaction. Blogs help learners work in context-centered settings that help them understand. By autonomously developing a blog of their studying, they allow students to build their own awareness (Kim, 2008).

\section{Theory behind Vlogging}

Utilizing blogs as a learning environment is based on the social constructivist view of learning which emphasizes the cognitive development of the learners by engaging them in the development of their understanding. Students tend to learn through social interaction. Through this social interaction, they acquire the target language naturally, automatically, and unconsciously. The role of vlogging here is to provide a context or an environment for social interaction to happen through 


\section{Dr. Hanan Ahmed Sanad}

providing a platform for students' feedback and practices (Hung, 2011: 737). Furthermore, Ko et.al. (2003) report that vlogging results in scaffolding as an important aspect of socio-constructivist when competent learners support the less competent ones helping them to construct knowledge. Aydin (2014:245) adds that constructing knowledge helps develop ideas collaboratively with peers and teachers. This happens when students use the language in different situations and discuss their ideas with classmates and move their knowledge among core skills, thereby, building a social learning context that facilitates cooperative learning.

Vlogging as a part of e-learning technology is an effective tool for creating an educational environment. Vlogs will support a wide range of teaching concepts and practices (Noel, 2005). Based on the constructivism theory, Chuang and Rosenbusch (2005) conducted a study that showed that the use of video technology has created possibilities to trigger interest for students and established a collaborative learning platform. Also, vlogs enhance independence among students (Wagener, 2006).

\section{Blogging in English language teaching}

Bacescu (2017) comments that blogs are resources with a hidden ability that can be used by teachers with the following benefits:

1. Improving reading skills and written ability.

2. Providing a learning experience that is free of space and time.

3. Motivating learners and arousing curiosity because the practice is trendy.

4. Encouraging and promoting communication skills.

5. Encouraging teachers to adopt new and oriented methods of teaching.

6. Giving learners a chance to express their learning needs and requirements.

Dudeney and Hockley (2008) identify three forms of Edu. blogs; student blog, tutor blog, and class blog. A tutor blog is set up by the teacher to provide learners with instructions, news, content, comments, extra practice of reading, online links, and home assignments. Learners can access the tutor blog under the permission of the teacher to add comments. The second type of Edu. blogs are the student blog, where the teacher encourages the learners to set up their blogs where others can post and comment. The third type is the class blog which is created by the teacher for all the class to comment and send their posts on certain topics. 


\section{Vlogging in education}

Recently, online videos have become one of the most important forms of all types of media. They are widespread and widely watched since their material is popular with the majority of fans. Videoblogging is one of those newest technologies that has created new communication channels through media created by the public. While video blogging is a revolutionary innovation and a phenomenon on the Web today, only a few video bloggers have anticipated and used the promises of video blogging for the educational environment (Baran, 2007).

People of different ages and from all around the globe create amazing communities around virtual media content by videoblogging. a significant shift to video learning is made. Moreover, the famous online learning platforms are not always the sole resources for e-learning for young people but do use Twitter, vlogs, Wikipedia, and forums (Bacescu, 2017 ; 373). Vlogging in education can be used as an efficient form of communication. It has been possible to use it in education to gain information and skills that cannot be obtained from conventional learning sources.

\section{Studies}

\begin{tabular}{|c|c|c|c|}
\hline Study & Variables & Sample & Results \\
\hline Hung, 2011 & $\begin{array}{l}\text { Video blog (vlog) } \\
\text { project \& students' } \\
\text { perceptions towards } \\
\text { vlogs }\end{array}$ & ESP students & $\begin{array}{l}\text { Students favourably } \\
\text { perceived the vlog project. }\end{array}$ \\
\hline $\begin{array}{l}\text { Combeand } \\
\text { Codreanu } \\
(2016)\end{array}$ & $\begin{array}{l}\text { Vlogs \& language } \\
\text { speaking } \\
\text { Skills }\end{array}$ & $\begin{array}{l}\text { American French } \\
\text { Language learner }\end{array}$ & $\begin{array}{l}\text { Using vlogs is effective in } \\
\text { sustaining learning of } \\
\text { language and speaking and } \\
\text { intercultural exchanges }\end{array}$ \\
\hline $\begin{array}{l}\text { Elgarawany } \\
(2017)\end{array}$ & $\begin{array}{l}\text { Vlogs \& EFL } \\
\text { presentation skills and } \\
\text { reflective thinking }\end{array}$ & $\begin{array}{l}\text { Students } \\
\text { specialized in } \\
\text { Tour Guidance }\end{array}$ & $\begin{array}{l}\text { Positive gains in in EFL } \\
\text { presentation skills and } \\
\text { reflective thinking }\end{array}$ \\
\hline $\begin{array}{l}\text { Maulidah } \\
\text { (2017) }\end{array}$ & $\begin{array}{l}\text { Vlogs and Speaking } \\
\text { skills }\end{array}$ & EFL students & $\begin{array}{l}\text { Vlog significantly } \\
\text { improves students' } \\
\text { speaking ability. }\end{array}$ \\
\hline $\begin{array}{l}\text { Singer, } \\
(2009) \text {. }\end{array}$ & $\begin{array}{l}\text { Blogging and Academic } \\
\text { Achievment }\end{array}$ & & $\begin{array}{l}\text { Positive effects of blogging } \\
\text { on school achievement }\end{array}$ \\
\hline $\begin{array}{l}\text { Watkins \& } \\
\text { Wilkins } \\
\text { (2011) }\end{array}$ & $\begin{array}{l}\text { Vlogs and oral } \\
\text { communication } \\
\text { classroom }\end{array}$ & - & $\begin{array}{l}\text { Using YouTube enhances } \\
\text { conversation, listening, and } \\
\text { pronunciation skills. }\end{array}$ \\
\hline
\end{tabular}




\section{Positive and negative impacts}

Studies by $\mathrm{Du}$ and Wagner (2006) and Lin et al. (2006) have shown that blogs have a great effect on learners' achievement. Noel (2015) reports many positive impacts of blogging in the field of learning such as supporting intellectual and cognitive engagement, creating a student-centered environment, making connections between ideas, supporting collaboration between peers and their instructors, providing feedback, exchanging ideas in addition to other positive effects on peerlearning.

On the other hand, others argue that blogs do not incorporate constructivism, especially in terms of intellectual and cognitive engagement. Robertson (2011) argues that blogging activities have no benefits or positive impacts on the mental argument because of the heavy workload that students endure such as reading, comprehending and commenting in addition to the difficulty of the content and the number of topics and concepts needed to meet the learners' abilities.

Another negative aspect is that the students' views on blogs could not help promote meaningful cognitive development. Deng and Yuen (2011) and Kerwalla et al (2009) comment that only about twenty percent of blog posts reflect students' meaningful reflections.

It is the lack of agreement on the efficacy of vlogs that researchers may be encouraged to conduct research, such as this research, to investigate the effectiveness of using videos in EFL learning.

\section{Oral communication skills}

Oral communication is an urgent skill in English language learning (Kayi, 2006). Oral competence refers to the ability to fluently and correctly communicate in a target language (Omaggio, 1986). An individual with a high oral proficiency level can use linguistic knowledge in new contexts and situations (Wiriyachitra, 2003). Many barriers to impeding oral ability include insufficient access to the meditated English environment. Much attention and focus should be given to the speaking skill as it can be considered the most important productive skill. Good speaking skills, for example, lead to promotions during formal speaking events, work preparation, business meetings, and many other business reasons (Osborn et al. 2008). Speaking skill or communication skill is the most important requirement in all job interviews or work experience.

Developing speaking or oral communication skills requires the teachers to provide the students with varied life-like contexts and chances to speak inside and outside class. These contexts should be set and designed in a way that urges students to communicate in different virtual as well as realistic situations. Stress should be put on vocabulary, grammar, collocations, and pronunciation to achieve fluency and 
accuracy as well. Manurung (2015) argues that progress in language learning is "often evaluated by the ability of learners to communicate in the language they are studying" (p. 45). Moreover, Harmer (2007) debates that language learners depend on the speaking skills they master when they speak. That is why there is always a need for and recommendation for further research to develop the teaching and learning strategies and approaches needed to encourage speaking skills that allow students to participate efficiently.

Al-Wossabi (2016) discusses aspects of developing oral skills exploited in language learning research and their relevance and suitability to EFL teaching in higher education in Saudi Arabia. He addresses issues including the significance and disadvantages of meaning negotiating process in both group work and pair work, the impact of using communication protocols on learner-to-learner oral communication, the significance of intonation, feedback, and the use of authentic materials. Walsh's (2002) argues that the teacher must involve learners, facilitate self-expression possibilities, promote interactional adjustment between educators, and finally enable learners to express themselves as a part of sharing responsibility.

\section{Motivation to learn English}

Motivation is the most significant aspect that helps learners to learn and achieve high scores in achievement tests. Success in learning a foreign language depends highly on having the motivation to learn. According to Al-Tamimi and Shuaib (2009), motivation might be one of the elements related to the students' low proficiency or success in the English language (p. 30). Therefore, there should be a full understanding of the learners' needs to better construct language teaching programs that motivate, engage, and urge students to learn. Motivation strongly affects how often learners use learning strategies, how much learners engage with native speakers, and how much feedback they obtain in the language they are learning (Matthews 2008).

A clear definition of the term "motivation" requires a full understanding of how it is viewed from different philosophies. In terms of behavior, motivation is simply the expectation of reward (Brown, 2000, p.160), and it is divided into intrinsic and extrinsic. Extrinsic motivation occurs when we are motivated to behave or engage in an action to earn a reward or escape punishment. Extrinsic rewards may be used to encourage people to learn new competencies or expertise. Whereas intrinsic motivation is the innate urge to look for and resolve obstacles as we seek personal goals and abilities to exercise. It is the 
motivation to do something without expecting to be rewarded by materials or activities outside the learning task.

The cognitivist view focuses on motivation as being related to the learners' decisions, the person's degree, and effort to approach or avoid something. The constructivists tend to focus on social contexts as well as the learner's decision. Motivation's effect in promoting English language learning is not deniable. Gardner (2006) comments that" the students' apprehension of engaging in and participating in EFL activities, especially oral skills activities, results from their lack of motivation". In turn, they do not show the persistence or enjoyment of activities.

Motivation can also be instrumental, integrative (Brown, 2000). It can be developmental or personal which includes watching films and reading books in English (Cooper \& Fishman, 1977, p. 243). Instrumental motivation refers to learning how to fulfill a task, such as passing a course, earning better pay, etc. (Ehrman, 1996, p.139). Instrumental orientation characterizes the foreign language's relation to the learners' goals. Integrative motivation is closely related to a positive perception towards the language learning process and potentially represents a desire to incorporate and adjust to a changing target culture by using the language (Gardner, 1985, p. 54). Integrative focused learners show enthusiasm in learning a foreign language and have positive group attitudes. They show greater and more enduring motivation than other learners. They have a deep desire to learn the language and their positive attitudes towards the learning situation. It is more likely to improve their commitment and performance in language learning (Gardner, 1985).

A considerable body of research has addressed motivation either directly or indirectly. Pineda (2011) aimed at improving conceptual awareness on the motivation and attitudes of students towards learning English as a second language by using both quantitative and qualitative study methods and techniques (interviews, class evaluations, and questionnaires).

Benson's (1991) findings reflect on the significance of integrative and personal goals as motivating factors among Japanese college students as he reports that "integrative and personal reasons for learning English are recommended over instrumental ones" (Benson, 1991, p. 34).

Akobirov (2017) examines a higher level of EFL - junior and senior college students at Bukhara State University on English language learning motivation. Motivation is divided into two types: Instrumental and Integrative. Kansas City Kansas Community College (KCKCC) students tend to study English instrumentally and integratively than they are at Bukhara State University (BSU) than their peers. 
Wimolmas (2013) proves that instrumental English language learning motivation is higher than integrative English language learning motivation among his group of students of 30 first-year undergraduate students at an international institute of engineering and technology in Thailand.

In Dubai, Qashoa (2006) carries out a study among high school students about Arab EFL learners. The research attempts to analyze the integrative and instrumental motivation of the students to learn English. It also attempts to consider the factors that influence the motivation of the learners. The results indicated that students got a higher degree of instrumental motivation than integrative one. However, the results showed that variables such as spelling, grammar, and vocabulary were extremely demotivating as they caused language learning difficulties.

Al-Tamimi and Shuib's (2009) research evaluates the ESP students' motivation in terms of three motivational types: instrumental, integrative, and personal. They describe the attitudes of the learners concerning the use of English in the financial, educational, English language, and the English speaking world culture. The results show that the subjects' increased support for foreign language learning is both instrumental and personal. The integrative reasons, however, proved to have the least effect on the motivation of the English language students.

Zanghar (2012) investigates whether Libyan students at EFL classrooms are inspired to learn English instrumentally or integratively. The study also looks at the motivation-accomplishment relation. A questionnaire was completed by all the students. They were asked to respond to 14 items reflecting their instrumental and integrative motivations for English study. Research results proved that students were highly motivated in terms of integrative and instrumental motivation. In the meantime, integrative motivation appeared a bit stronger than its instrumental motivation. The results of the study showed that EFL Libyan students were highly instrumentally and integratively motivated to study English, and their integrative motivation appeared to be a little higher than their instrumental motivation.

\section{The problem of the study}

Based on the researcher's experience, it was noted that foreign language classrooms that suffer from the lack of oral communication skills often neglect the use of the communicative approach to language teaching. Using the language orally is limited to the classroom and in an artificial way. At the same time, finding ways to practice the language outside the classroom is a challenge. Both teachers and students find it 
easy to practice reading, writing, or passive listening. However, pronunciation and oral fluency are neglected.

Al-wossabi (2016) assures that speaking skills are not given due priority or interest in many Saudi EFL classrooms. Although the course's objectives focus on developing speaking skills as one of the four language skills, they lack the realistic application that matches the students' needs and levels. This problem may result from the teachers' focus on the syllabus and exam competition. So, English is learned in an artificial way (Watkins, 2012: 196). EFL large class can be one big obstacle preventing the development of EFL learners' oral production skills. As a result, most learners have little interest in learning because they may rarely have the opportunity to talk in class. On the other hand, teachers try to control this large number of students that reaches one hundred students in one class by limiting their efforts to the writing skills to assess the accomplishments of the students and language skills. Hung (2011:738) argues that more attention should be devoted to audio blogs and text blogs. The use of vlogs in language learning has been explored with a few systematic attempts. There is little work into using video clips as blog entries to record and illustrate the creation of languages.

The present study thus attempts to examine the effect of using vlogs to develop oral communication skills and motivation of college students.

\section{Questions of the study:}

The current study tries to answer the following questions:

1. What is the effect of using vlogs in developing oral communication skills of EFL PYP students in the Humanities track in IAU.

2. What is the effect of using vlogs in developing EFL oral communication sub-skills of PYP students in the Humanities track in IAU.

3. How effective is the use of vlogs in promoting EFL college students' motivation to learn?

\section{Hypotheses}

1. There is a significant difference between the mean score of the study participants in the pre- and post-assessment of the oral communication test in favour of the post-assessment.

2. There is a significant difference between the mean score of the study participants in the pre- and post-assessment of the EFL oral communication sub-skills test in favour of the post-assessment.

3. There is a significant difference between the mean score of the study participants in the pre- and post-assessment of the motivation to learn scale in favour of the post-assessment. 


\section{Objectives of the study}

The current study aims at investigating the effectiveness of vlogs in developing oral communication skills and motivation of EFL college students at Benha University. It seeks to:

1. Develop oral communication skills of EFL college students at IAU.

2. Develop EFL college students' motivation to learn English language.

3. Integrate technology into teaching and learning EFL.

\section{Method}

\section{Participants}

The sample of the study includes a group of 166 students enrolled on the preparation year, humanities track in Imam Abdul Rahman Bin Faisal University, Dammam, KSA

\section{Design}

The study adopts one group, pre-post-test experimental group design.

\section{Instruments}

\section{Oral communication skills test with a rubric.}

\section{Aim of the test}

The test was used as a pre-post-test to measure the level of students and to measure the effect of vlogs on developing the experimental group's oral communication skills.

\section{Description of the test}

A pool of oral communication skills questions was prepared and used with students based on the topics chosen from their coursebook:

McClure, K., Vargo, M., Scanlon, J., Santamaria, J. C., Brooks, M., Craven, M., Sherman, K., ... Earle-Carlin, S. (2011). Q: Skills for success: listening and speaking. New York, N.Y: Oxford University Press.

\section{The validity of the test}

To ensure the validity of the test, it was submitted to a group of EFL professionals. They agreed on the test after a slight modification in the questions and their number.

\section{Reliability of the test:}

The test was administered to a group of EFL students out of the study sample groups and enrolled in the same department. The Pearson interrater reliability was calculated. The reliability coefficient was (.89) at the 0.01 level of significance.

\section{Scoring the test:}

An oral communication skills rubric that included the main language areas such as; content, vocabulary, grammar, pronunciation, and fluency was prepared. The rubric was used by the scorers to rate students' skills 
in the test. Each of the sub-skills was given 10 points out of 50 points for all the test.

\section{Motivation to Learn Questionnaire (MLQ)}

To determine the students' integrative/instrumental motivation towards learning the English language, the researcher adopted MLQ from Gardner's Attitude/Motivation Test Battery (AMTB) (the instrumental and integrative orientation scales) with little modification.

\section{Aim of the MLQ}

The MLQ aimed to examine the students' instrumental and integrative motivation to learn the English language. It was used in the study to measure the students' orientations in terms of two kinds of motivation; instrumental and integrative.

\section{Description of the MLQ}

The MLQ consisted of 21 sentences that identified the students' motivation to learn the English language. The MLQ was a 5-point scale adapted from the original 7-point Likert Scale Gardener's Attitude/Motivation Test Battery (1985). Sentences included reasons for studying the English language.

\section{The validity of the MLQ}

The MLQ was submitted to jury members, who were asked to determine the clearness of the questionnaire instruction and the suitability of the items to the students' level. They indicated that the questionnaire was valid and appropriate to students' level.

\section{Reliability of the MLQ}

The reliability of MLQ was measured by using Alfa Cronbach analysis. Reliability proved to be ( .914$)$. Therefore, the questionnaire was reliable.

\begin{tabular}{|c|c|c|}
\hline \multicolumn{3}{|c|}{ Reliability Statistics } \\
\hline $\begin{array}{c}\text { Cronbach's } \\
\text { Alpha }\end{array}$ & $\begin{array}{c}\text { Cronbach's } \\
\text { Alpha Based } \\
\text { on } \\
\text { Standardized } \\
\text { Items }\end{array}$ & $\mathrm{N}$ of Items \\
\hline .914 & .933 & 21 \\
\hline
\end{tabular}

\section{Treatment}

Before implementation, both study samples were pretested. The MLQ was also presented to them to examine their motivation to learn the English language.

At the beginning of the first semester of the year 2020-2021, a vlogging program was implemented to develop oral communication skills and motivation to learn among EFL students. The students met for 8 sessions, 2.5 hours a week. In the first session, students were given an idea about 
the research and its objectives. They were taught how to join the vlog created by the researcher. They were given the link to the vlog.

It was better to upload videos for native speakers about how to talk in different situations about different topics. Then, the students were asked to watch the video and analyze it both in class and at home putting their comments on the vlog. Then, they recorded their videos on their cell phones. The projector and the speakers were used to show their videos in class. Further comments were discussed by the classmates. Pronunciation notes were given through sessions.

Using the vlog has gone through the following steps:

1. Many videos were uploaded on the vlog concerning varied topics such as:

- What is a good job?

- How can you find a good job?

- Why do we study other cultures?

- Why do people immigrate to other countries?

- Why is vacation important?

- What is the best kind of vacation?

- Importance of sports.

- What makes you laugh?

2. All videos were set as drafts.

3. Every week, the researcher opened access to one or two videos on the same topic.

4. the students were prompted to watch the video and discuss the question(s) given as a comment under the video.

5. In class, the students were asked to form pairs or groups and apply what they have learned from the video in front of the class. They could record the speech or conversation using their phones and all the class listens to them through the speakers.

6. Once the practice on one topic was finished, the video(s) were published in the next one. Students had to comment and add their contributions to the videos on the vlog.

7. Following these procedures has helped the learners overcome and conquer their fear, shyness, and embarrassment.

\section{Results}

Based on data analysis using the SPSS package version (23), the following results were reached: 


\section{Dr. Hanan Ahmed Sanad}

\section{Results of Hypothesis (1)}

The first hypothesis states that" There is a significant difference between the mean score of the study participants in the pre and post-assessment of the oral communication test in favour of the post-assessment.

Table 1 presents the students' mean scores, standard deviations, t- value, and the level of significance of the pre and post-assessment of the study sample in EFL oral communication skills and subskills.

Table (1): " $t$ " test between the mean scores of the study group in the pre-

post assessment of the EFL oral communication skills and sub-skills.

\begin{tabular}{|c|c|c|c|c|c|c|c|c|}
\hline Skills & Test & Mean & $\mathbf{N}$ & $\begin{array}{c}\text { Std. } \\
\text { Deviation }\end{array}$ & $\mathbf{t}$ & df & Sig. & $\begin{array}{l}\text { Effect } \\
\text { size } \\
\text { (Cohen) }\end{array}$ \\
\hline \multirow{2}{*}{$\begin{array}{c}\text { Oral } \\
\text { communication } \\
\text { skills }\end{array}$} & Pre & 38.73 & \multirow{2}{*}{160} & 7.07 & \multirow{2}{*}{3.32} & \multirow{2}{*}{165} & \multirow[t]{2}{*}{001} & \multirow[t]{2}{*}{$\begin{array}{c}.25 \\
\text { (small) }\end{array}$} \\
\hline & post & 39.46 & & 6.91 & & & & \\
\hline \multirow[t]{2}{*}{ Content } & Pre & 7.61 & 166 & 1.58 & \multirow{2}{*}{4.47} & \multirow{2}{*}{165} & \multirow[t]{2}{*}{000} & \multirow{2}{*}{$\begin{array}{c}.34 \\
\text { (small) }\end{array}$} \\
\hline & post & 8.08 & 166 & 1.61 & & & & \\
\hline \multirow[t]{2}{*}{ Vocabulary } & Pre & 7.43 & \multirow[t]{2}{*}{166} & 1.58 & \multirow[t]{2}{*}{4.91} & \multirow{2}{*}{165} & \multirow[t]{2}{*}{.000} & \multirow{2}{*}{$\begin{array}{c}.38 \\
\text { (small) }\end{array}$} \\
\hline & post & 7.92 & & 1.58 & & & & \\
\hline \multirow[t]{2}{*}{ Grammar } & Pre & 7.56 & \multirow[t]{2}{*}{166} & 1.58 & \multirow[t]{2}{*}{1.74} & \multirow{2}{*}{165} & \multirow[t]{2}{*}{.084} & \multirow[t]{2}{*}{.13} \\
\hline & post & 7.70 & & 1.58 & & & & \\
\hline \multirow{2}{*}{$\begin{array}{l}\text { Pronuncia } \\
\text { tion }\end{array}$} & Pre & 8.60 & \multirow[t]{2}{*}{166} & 1.65 & \multirow[t]{2}{*}{5.816} & \multirow{2}{*}{165} & \multirow[t]{2}{*}{.000} & \multirow{2}{*}{$\begin{array}{c}.44 \\
\text { (small) }\end{array}$} \\
\hline & post & 7.93 & & 1.53 & & & & \\
\hline \multirow[t]{2}{*}{ Fluency } & Pre & 7.50 & \multirow[t]{2}{*}{166} & 1.62 & \multirow[t]{2}{*}{1.34} & \multirow[t]{2}{*}{165} & \multirow[t]{2}{*}{181} & \multirow{2}{*}{$\begin{array}{c}.10 \\
\ldots \ldots\end{array}$} \\
\hline & post & 7.54 & & 1.65 & & & & \\
\hline
\end{tabular}

Based on Table 1 the study sample showed little progress in the postadministration of EFL oral communication skills test, where the "t- value is (3.32) which is significant at the (0.01) level. Thus, the first hypothesis was supported.

\section{Findings of Hypothesis (2)}

The second hypothesis states that" There is a significant difference between the mean score of the study participants in the pre and postassessment of the EFL oral communication sub-skills test in favor of the post-assessment.

Table (1) shows T-value for oral communication sub-skills ; content ( $4.47)$, vocabulary (4.91), pronunciation (5.82) . These values proved to 
be significant at the level of .000 except grammar (1.74) and fluency (1.34) which showed no significant difference or no progress.

\section{Effect size:}

Cohen d reference:

- $\mathrm{D}=0.2$ is small effect

- $\mathrm{D}=0.5$ is a medium effect

- $\mathrm{D}=0.8$ is a large effect

Size effect was small in all sub-skills.

\section{Findings of Hypothesis (3)}

The second hypothesis states that there is a significant difference between the mean score of the study participants in the pre and postassessment of the motivation to learn in favor of the post-assessment.

Table 2 presents the students' mean scores, standard deviations, Tvalue, and level of significance of the pre and post-assessment of the study sample in EFL motivation to learn.

Table (2): "T" test between the mean scores of the study sample in the pre-post assessment of the EFL motivation to learn.

\begin{tabular}{|c|c|c|c|c|c|c|}
\hline $\begin{array}{c}\text { Motivation } \\
\text { scale }\end{array}$ & Mean & N & Std. Deviation & t & df & Sig. \\
\hline Pretest & $\mathbf{6 9 . 2 8}$ & $\mathbf{1 6 6}$ & $\mathbf{2 0 . 7 3}$ & 11.91 & 165 & $\mathbf{. 0 0 0}$ \\
\hline Posttest & $\mathbf{8 2 . 8 3}$ & $\mathbf{1 6 6}$ & $\mathbf{2 0 . 1 1}$ & $\mathbf{1 6 5}$ \\
\hline
\end{tabular}

Table 2 indicates that the study sample showed progress in the post-administration of EFL motivation to learn. The T-value is (11.91) which is significant at the (0.000) level. Thus, the second hypothesis was supported.

\section{Discussions}

The main objective of the current study is to examine the effect of using vlogging to develop EFL oral communication skills and motivation among PYP students of humanities track at Imam Abdul Rahman Bin Faisal University. The study includes different online activities and tasks that would help learners develop their oral communication skills. The results indicate that the Vlogs are statistically and instructional effectiveness in developing their oral communication skills and motivation to learn. The effect was small for many reasons that will be discussed later in this paper.

Vlogs offer a unique opportunity to practice speaking. This skill is usually hard to develop outside the classroom in an authentic communication context due to many reasons. Vlogs help students improve listening and speaking skills in front of a camera by introducing the curriculum and to promote publishing (speech acts and movements, refining the final media product before uploading, inserting text, and emoticons that demonstrate speech acts). Topics like lexicon and 


\section{Dr. Hanan Ahmed Sanad}

pronunciation generate interactions, communications, and talks which lead to rich arguments. Vlogging represents a perfect atmosphere for peer-learning and collaboration.

The findings of the study also indicate that vlogs offer participants a comfortable and friendly atmosphere to practice the target language. Designing their online videos to participate in the practice sessions develops the learners' automaticity. Vlogging (Video blogging) has a positive effect on improving learners' fluency, accuracy, and accent or language complexity. Since vlogging is mostly oral, speaking is the major component being emphasized through the sessions' practice. This was consistent with the results of Thomas ( 2009 ), Gao, Tian, Huang \& Yang, (2010), and Bacescu (2017).

AlHamadi (2014) assured that The ability to speak is the only ability that, among the other English language abilities, is difficult to learn effectively. Furthermore, it is not always possible to ascertain the reasons behind the student's lack of speaking.

Reviewing the educational system in Saudi Arabia through the three levels before college level, it can be concluded that the low level of students in the college preparation year is due to the lack of exposure to appropriate English input due to the small number of English classes, the low quality of teachers, the English language program and the teaching techniques being used in the class ( AlHamadi,2014)

PYP in IAU seeks to develop students' English language skills in the humanities track adopting the CEFR of Europe, but progress showed among this group of students is slow and sometimes impossible. The main reason is that humanities track students are classified based on their low level in high school without a placement test in the college. Their levels do not match the CEFR levels classified. Simply speaking, because A1 level according to the CEFR does not parallel with the low level in Saudi Arabia. There are so many barriers that must be put into consideration before applying the European framework borrowed from native English country to be applied on low levels of students in a country that suffers from failure in teaching and learning English especially the pre-college levels. This scenario prevails in almost all Saudi universities.

In her study, AlHamadi (2014) shed light on the weaknesses of the educational process in teaching speaking at Tibah University. She identified and evaluated the real causes of the educational system weaknesses as well as the weaknesses of the language teaching process at Tibah University. These weaknesses apply to the case of IAU preparation year students which is proved by the results of the current research. 
Improving pronunciation is one of the most important aspects of developing oral communication. In the IAU preparation program, there is no phonetics lab and the development of this aspect takes not that much attention. So, pronunciation is neglected and not given that focus.

Although the Q skills series of books studied provide varied language skills to be developed, neither the teachers nor the students can choose the skills which needed to be focused on according to the student's needs and abilities. This process applies to the exams applied. Among the obstacles that hinder the focus on oral communication skills is a load of books specified to be taught in the track per semester. Students are obliged to study four books which represent two levels that are higher than the actual level of students. This represents the load on teachers also as they do not find the time for practice using different sources.

To follow students' needs, levels in the humanities track need to be classified. Classification helps to teach according to students' pace of learning. No loads are effective. Deep learning is much better than surface learning. Thus, students' needs can be met.

AlHamadi (2014) pointed out other important psychological and pedagogical factors that hinder the development of speaking skills among Saudi students. Examples of which are English teaching strategies, students' motivation, anxiety, and students' apprehension to learn English.

Although students show a high motivation to learn English, the gap between strategies of teaching and learning at school and that of the college hindered the development of their speaking skills.

As mentioned earlier, motivation is one of the most significant psychological factors in the learning process. It reflects the students' readiness to participate actively, effectively, and enthusiastically in the conversations. Highly motivated students tend to take an active part in the learning process through the practice during sessions. According to Kaga (1994,p.1), the video blogging strategy is one of the challenging strategies that automatically urge the students to participate actively in the classroom since it has a good structure that appears in how it builds students' knowledge around individual responses.

In video-blogging sessions, the vlogger could gain more experience than in-text blogging. Creating a single video blog requires a combination of images, sounds, photos, and texts. Video-bloggers believe that video is more natural than writing and it was found consistent with the results of (Rakhmanina and Kusumaningrum, 2017) 


\section{Dr. Hanan Ahmed Sanad}

\section{Conclusion}

Vlogs are effective in teaching oral communication skills to university students. Highly motivated students tend to achieve better performance and reach higher competency levels than those with low learning motivation levels.

It is also clear that the participants show great interest in the use of vlogs for professional reasons. It contributes to their progress for so many reasons. It helps them recognize their shortcomings, work on them in the future in order not to be repeated, review, and evaluate their behaviors. In addition to providing social communication, information sharing, and discussion opportunities, the use of vlogs has exploited YouTube's ease of use, popularity, voting, and comment features. The pre-service teachers support the use of vlogs as they mainly offer a platform for expressing themselves comfortably.

\section{Recommendations}

Based on the previous results and conclusions, the following recommendations are suggested:

\section{EFL Teachers}

Teachers are recommended to focus more on communication skills. They should do their best to make the best use of the latest technology to increase the learners' motivation and enhance their engagement in the learning process. Teachers are advised to include vlogs into their teaching strategies as they create a unique atmosphere that encourages the learners to express themselves freely and confidently. If they are carefully chosen and well-designed, vlogs are engaging and enjoyable.

\section{For students:}

Vlogging provides chances for digital literacy skills and opportunities for peer learning which promotes the learners' autonomy. Moreover, vlogs offer an authentic life-like atmosphere in which the learners are exposed to everyday language. This requires students to be active and engaged thoroughly in the learning process to improve their oral communication skills. Students should be encouraged and motivated to participate actively, freely, and confidently in the conversations. They should be urged to practice their language communicatively and effectively.

\section{EFL curriculum designers}

Curriculum designers should integrate the use of technology into the strategies used in developing different language skills especially those which promote motivation and self-learning. 


\section{References}

Akobirov, F. (2017). The influence of technology on language learning and Motivation with Uzbek EFL and united states ESL students. A dissertation in Education submitted in partial fulfillment of the requirements for the Degree of Doctor of Philosophy

Alhmadi, N. S. (2014). English speaking learning barriers in Saudi Arabia: A case study of Tibah University. Arab World English Journal, 5(2).

Al-Tamimi, A., and Shuib, M. ( 2009). Motivation And Attitudes Towards Learning English: A Study Of Petroleum Engineering Undergraduates At Hadhramout University Of Sciences And Technology. GEMA Online Journal of Language Studies Volume 9(2), pp. 29-55. ISSN: 1675-8021

Al-wossabi, S. (2016). SLA Classroom Research and EFL Teaching Practices of Oral Skills. Theory and Practice in Language Studies, Vol. 6, No. 11, pp. 2061-2067, November 2016

Anil, B. (2016). Top-Up Students Second Language Talk Time through Vlogs. Indonesian Journal of EFL and Linguistics, 1(2), 129-143.

Bacescu, M., C. (2017). Blogging, vlogging - from entertainment to education. The 13th International Scientific Conference eLearning and Software for Education, Bucharest, April 27-28, 2017. 10.12753/2066-026X-17-054

Baran, E. (2007). The promises of videoblogging in education. In 2007 Annual Proceedings. Selected Papers On the Practice of Educational Communications and Technology Presented at The Annual Convention of the Association for Educational Communications and Technology Sponsored by the Research and Theory Division (Vol. 2, No. 30, pp. 10$18)$.

Benson, M. J. (1991). Attitudes and motivation towards English: A survey of Japanese freshmen. RELC journal, 22(1), 34-48.

Bojović, M. (2006). Teaching Foreign Language for Specific Purposes: Teacher Development. Association of Teacher Education in Europe. $31^{\text {st }}$ annual ATEE conference.pp487-493.

Bracaj, M. (2014). Teaching English for specific purposes and teacher training. European Scientific Journal. vol.10, No.2 ISSN: 1857 - 7881 (Print) e ISSN 1857- 7431

Brinton, D. (2001). The use of media in language teaching. In M. Celce-Murcia (Ed.), Teaching English as a second or foreign language (pp. 459-476). Boston, MA: Heinle \& Heinle

Brown, H.D. (2000). Principles of language learning and teaching (4th Ed.). Englewood Cliffs NJ: Prentice-Hall.

Cambridge Advanced Learner's Dictionary and Thesaurus. (n.d). Vlogs. In Cambridge Advanced Learner's Dictionary and Thesaurus. org dictionary. Retrieved July 14, 2020, from https://dictionary.cambridge.org/dictionary/english/vlog 


\section{Dr. Hanan Ahmed Sanad}

Comas-Quinn, A., Mardomingo, R., \& Valentine, C. (2009). Mobile blogs in language learning: Making the most of information and situated learning opportunities. ReCALL, 21(1), 96-112.

Combe, C., \& Codreanu, T. (2016). Vlogging: A New Channel for Language Learning and Intercultural Exchanges. Research-publishing. net.

Cooper, R. L., \& Fishman, J. A. (1977). A study of language attitudes. En J. L. Fishman, The spread of English. (págs. 239-276). Rowley, MA: Newbury House

Deng, L., \& Yuen, A.H.K. (2011). Towards a framework for educational affordances of blogs. Computers and Education, 56, 441-451.

DOI: http://dx.doi.org/10.17507/tpls.0611.01

Du, H.S., \& Wagner, C. (2006). Weblog success: Exploring the role of technology. International Journal of Human-Computer Studies, 64, 789798

Dudeney , G. and Hockly N. (2008). How to Teach English with Technology . ELT Journal, Volume 62, Issue 4, October 2008, Pages 25-28

Ehrman, E. (1996) Understanding Second Language Learning Difficulties. London: Sage Publications.

El-Garawany, M. S. M. (2017). The Effect of Vlogging on Developing Tour Guidance Students' EFL Presentation Skills and Reflective Thinking. Journal of Research in Curriculum Instruction and Educational Technology, 3(1), 43-79.

Essays, UK. (November 2013). Instrumental And Integrative Motivation English Language Essay. Retrieved from https://www.ukessays.com/essays/english-language/instrumental-andintegrative-motivation-english-language-essay.php?cref $=1$

Fălăuş, A. (2016). The current challenges of teaching ESP. Innovative Ideas in Science. IOP Conf. Series: Materials Science and Engineering 200 (2017) 012059 DOI:10.1088/1757-899X/200/1/012059

Gao, W., Tian, Y., Huang, T., and Yang, Q. 2010. Vlogging: A survey of video blogging technology on the Web. ACM Comput. Surv. 42, 4, Article 15 (June 2010), 57 pages. DOI $=10.1145 / 1749603.1749606$, http://doi.acm.org/10.1145/1749603.1749606

Gardner, R.C. (1985). Social psychology and language learning: The role of attitudes and motivation. London, Ontario: Edward Arnold.

Hoa, N.T., and Mai, P.T. (2016). Difficulties in Teaching English for Specific Purposes: Empirical Study at Vietnam Universities.Higher Education Studies; Vol. 6, No. 2;

http://thefuturebuzz.com/2009/01/12/social-media-web-20-internet-numbers-stats

Hung, S., T. (2011). Pedagogical applications of Vlogs: An investigation into ESP learners' perceptions. British Journal of Educational Technology Vol 42 No 5. pp 736-746 DOI:10.1111/j.1467-8535.2010.01086.x ISSN 1925-4741 E-ISSN 1925-475X 
Janulevičienè, V., and Kavaliauskienè, G. (2011). English for Specific Purposes \& public speaking. Comparative study. Societal Studies, 3(2), p. 709-720.

Kaga, Spencer. (1994). Cooperative learning. San Clemente, CA: Kagan Publishing.

Kayi, H. (2006). "Teaching Speaking: Activities to promote speaking in a second language," The Internet TESL Journal, vol.12, no.11. Retrieved from http://iteslj.org/Techniques/KayiTeachingSpeaking.html

Kerawalla, L., Minocha, S., Kirkup, G., \& Conole, G. (2009). An empirically grounded framework to guide blogging in higher education. Journal of Computer Assisted Learning, 25(1), 31-42.

Kim, H.N. (2008). The phenomenon of blogs and the theoretical model of blog use in educational contexts. Computers and Education, 51, 1342-1352.

Leung, A. (2004). Fostering learner autonomy among weak students via information technology. The HKU Scholars Hub. Retrieved from http://hdl.handle.net/10722/30657

Lin, W., Lieu, Y., Kakusho, K., Yueh, H., Murakami, M., \& Minoh, M. (2006). Blog as a tool to develop e-Learning experience in an international distance course. In Proceedings of the Sixth IEEE International Conference on Advanced Learning Technologies, 290-292.

Lorenzo, F. (2005). Teaching English for Specific Purposes, https://www.usingenglish.com/articles /teaching-English-for-specificpurposes-esp.html

Manurung, K. (2015). Improving the speaking skill using reading contextual internet-based instructional materials in an EFL class in Indonesia. Procedia-Social and Behavioral Sciences, 176, 44-51.

Matheson, D. (2004). Weblogs and the epistemology of the news: some trends in online journalism. New Media \& Society, 6, 4, 443-468.

Matthews, P. H. ( ). Achievement Motivational Characteristics of University Foreign Language Learners: From the Classroom to the Tutoring Table. Foreign language annals * VOI. 41, NO. 4 611-626.

Maulidah, I. (2017, August). Vlog: the Mean to Improve Students' Speaking Ability. In International Conference on English Language Teaching (ICONELT 2017). Atlantis Press.

Mohamed, A. AL Yateema, A., and Alsayadi, S. (2015). Designing educational blogs effect on the student's knowledge acquisition in the second stage: A case study of KSA Schools. Procedia Computer Science 65 ( 2015 ) $519-528$

Noel, L. (2015). Using blogs to create a constructivist learning environment. Procedia - Social and Behavioral Sciences 174, pp. (617 - 621)

Omaggio, A. , C. (1986). Teaching Language in Context: Proficiency-oriented Instruction. Boston: Heinle \& Heinle Publishers.

Osborn, S., Osborn, M., \& Osborn, R. (2008). Public speaking guidebook. Boston: Pearson. 


\section{Dr. Hanan Ahmed Sanad}

PĂCURAR, E. (2015). Assessing speaking - autonomy, and automaticity in ESP. The 11th International Scientific Conference e-Learning and Software for Education, Bucharest, pp441-446.

Qashoa, S. H. H. (2006). Motivation among learners of English in the secondary schools in the eastern coast of the UAE (Doctoral dissertation, The British University in Dubai (BUID).

Rakhmanina, L., \& Kusumaningrum, D. (2017). The effectiveness of video blogging in teaching speaking viewed from students' learning motivation. Proceedings of ISELT FBS Universitas Negeri Padang, 5, 2734.

Robertson, J. (2011). The educational affordances of blogs for self-directed learning. Computers and Education, 57, 1628-1644.

Rus, D. (2015). The acquisition of oral communication skills in an ESP class. Discourse as a form of multiculturalism in literature and communication. Section: language and discourse archipelago xxi press, tîrgu mureș, 2015, ISBN: 978-606-8624-21-1 pp.113-120

Sandoval-Pineda, A. (2011). Attitude, Motivation, and English language learning in a Mexican college context. A Ph.D submitted in partial fulfillment of requirements for an advanced degree at the University of Arizona in the Graduate College

Saygili, H. K. (2014). Fostering Speaking Strategies of ESP Students via Drama: Case Study. An MA thesis, Istanbul Şehir university

Singer, A. (2009). Social media, Web 2.0, and internet stats. Retrieved, January 12, 2010, from :

Sultan, S., and Hussain, I. (2010). Significance of Instrumental and Integrative Motivation in Second Language Acquisition . Journal of educational research (Vol.13 No.2) pp. 145-152

Thomas, M. (2009). Producing Cell Phone Video Diaries. In M. Thomas (Ed.), Handbook of Research on Web 2.0 and Second Language Learning (pp. 260-272): Idea Group Inc (IGI).

Walsh, S. (2002). Construction or obstruction: teacher talk and learner involvement in the EFL classroom. Language Teaching Research, 6(1), 323.

Watkins, J., \& Wilkins, M. (2011). Using YouTube in the EFL classroom. Language Education in Asia, 2(1), 113-119.

Wimolmas, R. (2013). A survey study of motivation in English language learning of first year undergraduate students at Sirindhorn International Institute of Technology (SIIT), Thammasat University. Language Institute, Thammasat University.

Wiriyachitra, A. (2003). Thai teachers' role in teaching: Motivating students and guiding their learning. Thai TESOL Focus, 16(2), 25-27.

Zanghar, A. (2012). Instrumental and integrative motivation among undergraduate Libyan students of English as a foreign language. MA thesis, Department of English, Colorado State University. 